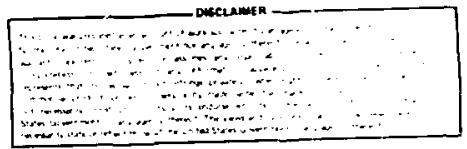

SENSITIVITY STUUCES OF THت̈. SHIF RWIONUCLIDE TRASPORT WUEL

James E. Campbell, Brenda S. Langkopf, Ronald L. Imah, Sandia Laboratories, $A$ lbuque rque, New Nexico

Mark Reeves, IrTERh Envi ronmental Consultants, Houst on, Texas

\title{
I. INTRODLICTION
}

Risk analysis is a vital part of any safety assessment of a proposed nuclear waste depository. Risk analysis results are expressed in terws of radiation-1nduced health effects and are ca].culated using mathematical nodels. These models describe the following processes: (1) radionuclide migration in groundwater from the depository to a discharge point in the surf;ce environment, (2) radionuclide alzration and accumulation in the surface envi ronment, (3) buman uptake, and (4) radlation dostmet ry and health effects. There are large uncertalnties assoclated with many of the laput varlables to these mode's so that ranges, rather than point values, are of ten specifled. Consequently, the risk estimates thenselves have large uncertalnties. Tinerefore, point estimates of risk, without an indicatlon of the possible distribution of results, are probably neaningless and may be atsleading.

Given the limportance of quantifying uncertaincles in risk est Imates, it is clearly important to 1dentify thuse input varlables which are major contributors to uncertainey in model output. It is also laporiant to estabilsh technlques to generate model output distrlbutions with a limited number of computer runs for assumed ranges and distributions on model Input variables. Such is the purpose of a sensitivity analysis.

The work reported here is part of a larger prograw funded by the Nuclear Regulatory commisston to deve Iop a risk assessment nethodology for geclogle disposal of rádloactive wasie. 
Two 1mpurtant parts of this methodology were used in this study, nimely a nunertcal geosplere transport simulator and statistical techuiques for unalyzing transport calculations. The transport sibulat or is the Sandla Waste lgolation $F$ low and $T$ ransport (SWIFT) code [DIllon, Lantz, aid Pahwa, 1978]. It is a threedimensional, fintte-difference model which solves conservation equations for fluld flow, heat transport, (possibly non-t race) solute mass, and radlonuclides in trace quantitites. The statistLcal techniques package (Iman, Helton, and Campbel1, 1.978! were designed to reduce the number of transport calculations and still aake possible a rellable identification of important input variable.. These wethods are discussed further in section III. To demonst rate the application of the transport and statistical wathods, we have chasen a reference site and a particular depositury-bruachnent scenarlo. The physical problen is described in the next section, and results from the sensitivily ana Iysi.s are prosented in bection IV.

\section{PHYSICLL RROBLA}

The sensitivity analysis described in this paper was applied to a strictly hypothetical system. This systed consists of both a reference stte contalning a nuclear waste depository (Campbeli, et al., 1978] and a disrupive-event scenarlo for the possible release of radloactive materials from the depository to the biosphere. The reference site is located in a symetrical upland valley and is shown in cross-section In Figure 1.

The irest of the ridge surrounding the valley is at an elevation of b000 ieet, and the crest is a surface- and grouadwater divide so that the only water moving in the valley falls i. the valley ttself. The valley is dralned by a thajor rlver, River L, which is dt elevation 2500 feet. Tributaries to Rlver L exist, such as River $v$, but they are nomally dry. r!e valley recelves 40 lnches of ralnfall per year, of which 16 inches are lost by evapotransplration and the remaining 24 inches recharge the groundwater system. The geology of the site is a iso shown in Figure 1. The valley is underlain by crystalline bedrock whlch crops out only over a narrow width at the ridge crest surrounding the valley. This bedrock is assumed to be impermeable to sroundwater flow. Over the bedreck is a sequence of sedimentary rock as shown in figure 1. Nonlna: values of all hydraulic and thernal properties are given in Campbell, et al. [1978).

One dis ruptive event which corcelvably could release radloact ive waste frou a depository sucl as that of the reference site 1 , the formation of a $t$-tube. Here we assure seal fallures of a shaft ( 30 feet in dlameter) on the up.dip side and of a borehole ( 3 feet in dlameter) on the down-dip 


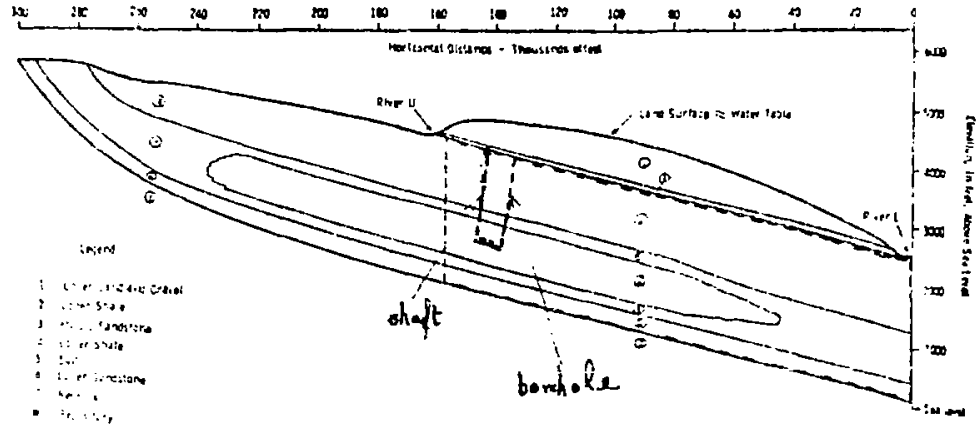

ind curnesten

$y+i x+s$

Flgure 1. veologic Cross-Section Through Reference site

side. The shaft, fur example, could be a man-baterlais cuniection to the surtace, and the borehole could be a venttletton plpe. The $\mathrm{U}$-tube, as shown in Figure 1 , provides a liug jath between the depository ind the upper aquifer. Tire itsalt als tcrehole are not extended through the upper shale and upder sand and gruvel as there is no signt: cant vertical hydriulfe gradient.

Nuge rical simulations have been carried out for the itill two-dintensional system of Figure 1 and for some selicted threedizensional systers in the near fleld of the depository using the SWIFT computer code. For the sensttivity analysis, however, a slmplified one-dimensional representation of the fuil systern and the U-tube was used. This representation is shown is a dashed ilne In Figure 1. Fluid flow in the simplifted system was established using pressure houndary conditions taken from a full-system simulation, and radionuclides we re lat roducud into the system frow an assumed inventory and leach rate.

As indicated in the Int roduct 1 on, fluid flow and rajionuclide transport are controlled by hydrological and geochemlcal variables whose values are nat generally well known for an? given site. For the reference site, this uncertainty was defined by the Delphi wethod. Earth scientists from Sandia Labotatories, the U.S. Geologica 1 Survey and INTERA Environgental Consultants were assembled for the purpose of assigniag a range and a distribution to each hydrological and geochemical parameter. 
The results of this effort are shown in Table J. for the simplifed U238 chain, U238 $\rightarrow \mathrm{U} 234 \rightarrow \mathrm{Th230} \rightarrow$ RA226. The ranges chosen a re global in nature and, as such, are somewhat broader chatl one aight reasonably expect for a particular site.

Table 1. Parameter Ranges and Distribu:Lons

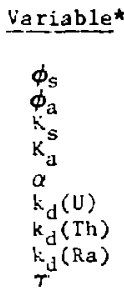

$$
\begin{aligned}
& \text { Range } \\
& 0.005-0.20 \\
& 0.05-0.30 \\
& 0.01-50 \mathrm{ft} / \mathrm{d} \\
& 1.0-50 \mathrm{ft} / \mathrm{d} \\
& 45-500 \mathrm{ft}^{3} \\
& 10^{-2}-10^{5} \mathrm{~cm}^{3} / \mathrm{s} \\
& 10^{-2}-10^{5} \mathrm{~cm}^{3} / \mathrm{g} \\
& 10^{-2}-10^{3} \mathrm{~cm}^{3} / 8 \\
& 10^{3}-10^{7} \mathrm{y}
\end{aligned}
$$

Distribut ion

Log Nomal

Nu ma 1

Log Notmal

iog Norma 1

Uniform

Log Uniform

Log Unifort

Log Uniform

Log Unifom

* Va riable definitions:

$\zeta=$ porosity, $K=$ hydraulic conductivity, $a=$ dispersivity,

$h_{\mathrm{d}}=\mathrm{distribution}$ coefficlent, $T=$ leaching time of a constantrate leach model, $s=$ shaft and borehole, $a=$ aquifar.

\section{DESCRIPTION OF STATISTICAL' METHODS}

For the physical problem described above, we present results for the total (integrated) radionuclide discharge in the lus-year time perlod following depository closure. The pertinent quest fons a re:

1. Which variahles, of those listed in Table 1 , have a significant effect upon the total discharge and what is their relative importance?

2. What relationships exist between the distributions of mode $i$ input and model output?

Conceptually, the manner in which the first question is answejed is based on a simple geometrical picture such as the one shown in Figure 2. The dependent varlable $Y$ is given as a furction of the two independent varlables $x_{1}$ and $x_{2}$ over their respective ranges. Surface $S$ is called the response surface. In general, the value of the dependent varlable $Y$ is known only at certain discrete points (i.e., for particular values of $X_{1}$ and $x_{2}$ ) as 1ndicated by the crosses in Figure 2. In the physical problem addiessed in this paper, the discrete points are known as a result of transport calculations with the SWIFT code. The 


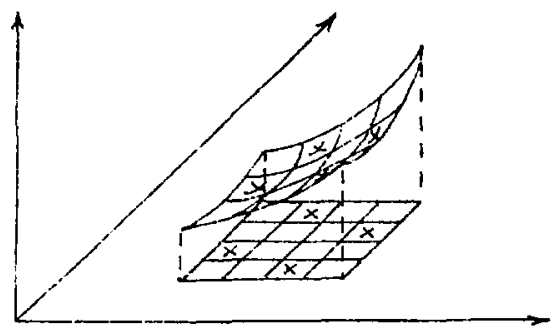

Eltting of the response surface by stepwise regresston is of central inportance to the sensitivity znalysis as this process selects the important independent variables. In addition the standardized regression coefficlents derived from the regression and ly is provide a basis for determining the relative loportance of the intependent variables. Thus, the first question posed at the beginning of this section may be answered through responsesurface construction.

tlthough simple In concept, respouse surface constructicn involves several statistical procedures. There is, for example, preliminary varlable assessuent usling partial correlation cuefFicients, stepwlse regression for const ruction of the response surface, protection agalnst overfit, use of t-test to estabilsh significance levels for the independent varlables, and varlous testis to exame the effect of Input varlable distribution assurptiors on the output varlable discitbution. Detalls of these procedures can be found in Iman, Helton and Campbell $[1978\}$ and in Feferences cited therein. Here, however, we wish to highlight two relatively new statistical techniques which we re ised.

The first technique is Latin Hypercube Sampling (LiSS) [Mckay, Conover, and Beckman, 1970] which mimimizes, relative to other commonly used schemes, the number of model calculations required for response surface construction. (For the numerical radionuclide transport slinulator used here, the calculations can be quite expensive.) LHS yields a global selectlon of points and tine fitied response surface ylelds an unbiased estimate of cumulative distribltulons functions and mean values for the model output. It $1 \mathrm{~s}$ for these reasons that LHS is being used for sensitivicy and risk analysis.

A brief description of LuS is provided in the following discussion. First the Independent varlabie ranges $\mathrm{x}_{1}$ are divided Into Intervals $I_{j 1}$ based on equal probibllicy. Values $I_{j 1}$ are 
then randowly selected from each of chese lintervals. Secondly, the values $T_{j i}$ are randomly mixed for each of the variables $x_{1}$ to form the input vectors. For the simple four-polnt example of Flgure 2 each varjabje cange 1u divided as shown below,
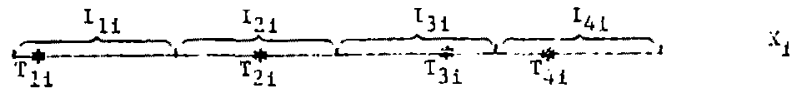

and the four Input vectors of independent vartabies ate $T_{1}=\left(T_{31}, T_{12}\right), T_{2}=\left(\mathrm{T}_{11}, T_{22}\right)$ a ari $T_{3}=\left(T_{41}, T_{32}\right), T_{4}=$ $\left(T_{21}, T_{42}\right)$.

The second technique troo the response sutiace rethodology which we wish to highligat is rank regte:sion (Iman and Conover, $1979 a]$. The rotivation here stetas from the nonlinearlly which is frequently present in the depende:ice $Y=f\left(x_{1}, X_{2}, \ldots\right)$ of the basic response varlatile upon the intepcndent viriables. It, however, the depenience is monotone, $a_{1 ;}$ it frequently is for transport calculacuas, then it may be linearlzed with the ralk r ransfomation. The concept of a ra:k eransform is simple in that each variable (independent and dependent) is replaced by jts corresponding rank. Fos exanple, the smalle: valu- $2 f \dot{x}_{i}$ 15 replaced by the rank $i$, the next emalles $b$; the rank 2 , did so on. Thus the ariofnal discrete valued function le replacted by the rank-trangformed funct lon $R\left(Y^{\prime}\right)=f\left[R\left(X_{1}\right), R\left(X_{2}\right), \ldots\right]$. It is this transformed functlon which is fitted with a responstsurface ustag stepwlse regression and phleh is usea to Establish the significance and relative tmportance of the iadependent variables.

To answer the second question posed at the beginning of this section, i.e., the relattonship of distributions of putput varlables to the assumed distributions of iaput vitiables, we can either propagate new dist tibutions through the iitted response surface or rewelght the base set of talia hypercute input vectors as outlined $1 \mathrm{n}$ Inan and Conover $\{1979 \mathrm{~b}\}$ to reflect different distrlbution assumplions. This aspect of the analyis thus provides a means of assessing the sensltuity of rodel output to the distribution assumptions of the input variables. The utility of this procedure is demonstrated 1\%. che next section for the physical prablen discussed in section II.

IV. RËSULTS AÑD CONCLUSIONS

To Identify the important input varlables for the systen desczibed in Section II and to establish relative importances of these quantitites, stepwise regression analysis was performed on the total discharge to Rlver L. The ranking of input variables for total discharge is shown $1 \pi$ Table 2 . 
Table 2. Input Vartable Ranking for Total Discharyt.

\begin{tabular}{|c|c|c|c|}
\hline $\mathrm{U} 238$. & $\underline{\mathrm{U}} 234$ & $T+1<3 u$ & $\unrhd$ N22 $^{2} 6$ \\
\hline$\left.k_{d}, U\right)$ & $\begin{array}{l}K_{d}(U) \\
\tau \\
K_{3} \\
\phi_{a}\end{array}$ & $\begin{array}{c}k_{d}(T h) \\
T_{a} \\
\phi_{i}\end{array}$ & $k_{d}(R a)$ \\
\hline $\begin{array}{l}30 \\
0.657\end{array}$ & $\begin{array}{l}28 \\
0.850\end{array}$ & $\begin{array}{l}39 \\
0.9 i j 9\end{array}$ & $\begin{array}{l}47 \\
\text { J. } 585\end{array}$ \\
\hline
\end{tabular}

The number $\mathrm{N}$ of nonzero values for each isotope which we re used in the stepoige regression analysis are sinown th the table. (Runs which produced no discharge during $10^{6}$ yaars we re oritled.) The $\mathrm{R}^{2}$ values, if multiplied by 100 , represent the percent of the output variation (expressed in ralas) which is a:signed to the input variables selected by stepwise rejrassion.

For each isotope, the distribution coefflelent id ranked is the most Important varlable. The leacli rate $I$, hylraulir conductivity in the aquifer $K_{a}$ and shaft $K_{s}$, dild shaft porusity $s$ enter as less iupartant variables.

Figure 3 shows cumulative distributions of total discharige for $U 238$. The solid line represents results from the original SWIFT calculations. Even only 30 nonzero values we re used to Fit the resfonse surface, the agreement is quite good. The agreegent be ween SWIFT and the response surface curves for U234, TH7.39 and RA226 (not shown) is of similarly high quallty.

Hijure 4 shows cunulative distributions of total discharge For U238 whe re zero values have been included. These results are included to show the sensilivity of SWIFT output to the distribution assumption for the distributio: coefficient $\left(K_{d}\right)$. The curve labelled LU represents the orfglnal SWLFT results where a log-unifon distribution was used Ear the $k_{d}$ values. To obtain the curve labelled $L W$, the origlnal input vectors were reweighted to represent a log-nomal distribution for the $k_{d}$ values.

In conclusion we note four things: (I) Uur sirulation and statistical techniques appear to be applicable to a fieldscale waste-isolation problem. (2) Transport variables have been constructed with less than 50 calculations b: the geospherecransport simulator. (3) The dispersivity is uniruportant because total teleases are used, and the refore, detalis of the shape of the breakthrough a re untmportant. (4) The dominance of the distribution coetficlent In each case is reasonable In view of the racher large values of the upper bound for this quanticy $\left(10^{5} \mathrm{~cm}^{3} / \mathrm{g}\right.$ for $\mathrm{I}$ and Th and $10^{3} \mathrm{~cm} / \mathrm{g}$ for $\left.\mathrm{Ka}\right)$. 


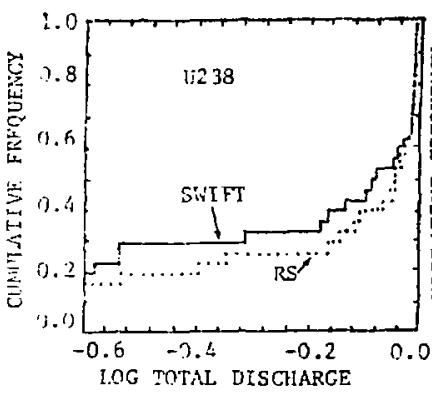

Figure 3, Cumulative distributions of total discharge relative to source. The solld 1 ine represents results from SWIFT. The docted 1 the represents results from fltted resm ponse surface. Calculations which produced zero discharge a re excluded.

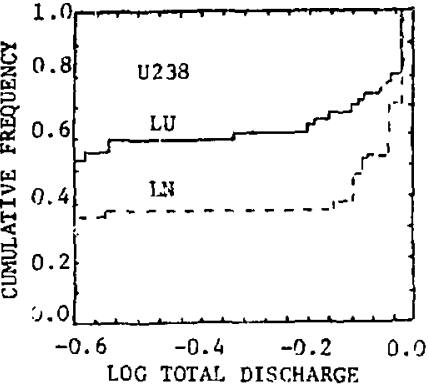

Figure 4. Cuaralative distefbulions of total discharge relative to source. The solid ine represents results $[$ rom Silf w Ith $10 \mathrm{~g}$ uniform distributions for $k_{d}$ values. The dashed line was obtalned b) rewaeigtting swIfI results to represent log nomal dis$t$ ributions on $k_{d}$ values.

\section{BIBLIUGRIPHY}

Campeli, J.E., et al. (19/8), "Risk Methodology for Geologlc Disposal of Radloactive Waste: Interin Report," SAivf 8 -0029, Sand1a Laboratories, Albuque rque, NM.

alllon, R. T., Lantz, R. B., and Pahwa, S. B. (1978), "Risk Nethodulogy for Geologic Disposal of Radioact lve viaste: The Sandfa Waste lsolation Flow and Transport (SNIFT) Madel, SANU78-1267, Sandia Laboratorles, Albuque rque, $M$.

Iman, R. L. and Conver, W. Jo (1979a), "The lise of the Rank Transformation in Regression," TECHOMETRICS, 21 , io. 4, (to appedr).

Iman, R. L., and Conover, W. J. (1979b), Small Sample Semsitivity Analysis Techniques for Computer Models with Application to R1sk Assessment," suogitred to Commintcations in statistics.

Iman, R. L., Helcon, J. C., and Campbell, J. E. (1978), "Risk Methodology for Geologic Disposal of Radloactive Waste: Senstivity inalysis Technlques, SAND78-U91.2, Sandia waboratories, Albuque rque, $\mathrm{NM}$.

Mckay, :A. D., Conover, W. J., and Becktan, R. J. (1979), "A Comparison of Three Methods for Selecting Values of Input Variables in the Analysis of Output from a Conputer Code, to anpear in TECHNOMETRICS. 